\title{
Kidney Cyst
}

National Cancer Institute

\section{Source}

National Cancer Institute. Kidney Cyst. NCI Thesaurus. Code C3970.

Abnormal fluid filled sac within the kidney, either acquired or cong enital. 